\title{
The Santa Luz chromite-peridotite and associated mafic dykes, Bahia-Brazil: remnants of a transitional-type ophiolite related to the Paleoproterozoic $(>2.1$ Ga) Rio Itapicuru greenstone belt?
}

\author{
Elson Paiva Oliveira ${ }^{1}$, Mônica Escayola ${ }^{2}$, Zorano Sergio Souza ${ }^{3}$, Juliana Finoto \\ Bueno $^{1}$, Marcelus Glaucus de Souza Araújo ${ }^{4}$ \& Neal Mcnaughton ${ }^{5}$
}

\begin{abstract}
The Santa Luz chromite-rich peridotite complex crops out in the Serrinha Block (NE São Francisco craton), approximately between grey gneisses of the Archaean basement and supracrustal rocks of the Palaeoproterozoic Rio Itapicuru greenstone belt. It comprises serpentinite, serpentinised harzburgite, massive chromitites, gabbroic pockets and amphibolite dykes/veins with epidote-rich margins, all intruded by pegmatite and aplite dykes. The mafic-ultramafic rock association is interpreted as basaltic melt percolation through mantle peridotites. Massive chromitites show major element chemistry and platinum group elements signature similar to ophiolite chromitites. The complex is older than $2085 \pm 12 \mathrm{Ma}$ and younger than $2983 \pm 8 \mathrm{Ma}$ based on $\mathrm{U}-\mathrm{Pb}$ ages obtained respectively on aplite dyke and host banded gneiss. The Santa Luz peridotite complex and associated mafic dykes may be related to rifting of a magma-poor continental margin that later evolved into an ocean, the closing of which eventually formed the Palaeoproterozoic Rio Itapicuru greenstone belt.
\end{abstract}

Keywords: transitional ophiolite, melt impregnation, magma-poor rifted continental margin, palaeoproterozoic greenstone belt, São Francisco craton.

\begin{abstract}
Resumo O peridotito cromitifero de Santa Luz e diques máficos associados, Bahia-Brasil: remanescentes de um ofiolito transicional relacionado ao greenstone belt paleoproterozóico $(>2.1 \mathrm{Ga})$ do rio Itapicuru? O complexo peridotítico de Santa Luz ocorre no Bloco Serrinha (NE do Cráton do São Francisco), aproximadamente entre gnaisses do embasamento arqueano e rochas supracrustais do greenstone belt do Rio Itapicuru. Ele contém serpentinitos, harzburgitos serpentinizados, cromititos maciços, faixas gabróicas e diques/veios de anfibolitos. Todo o conjunto é cortado por pegmatitos e aplitos. A associação máfica e ultramáfica é interpretada como percolação de magma basáltico em peridotitos do manto. Os cromititos maciços apresentam química mineral e padrões de elementos do grupo da platina semelhantes aos de cromititos de ofiolitos. O complexo é mais antigo que $2085 \pm 12$ Ma e mais novo que $2983 \pm 8 \mathrm{Ma}$, idades obtidas respectivamente em dique aplítico e gnaisse bandado encaixante. O complexo peridotítico de Santa Luz e os diques máficos associados podem ser relacionados à fase rifte de uma margem continental pobre em magma, a qual evoluiu para a abertura de um oceano e posteriormente se fechou para finalmente formar o greenstone belt do Rio Itapicuru durante colisão continental no Paleoproterozóico.
\end{abstract}

Palavras-chave: ofiolito transicional, rifte de margem continental pobre em magma, greenstone belt paleoproterozóico, Cráton do São Francisco.

INTRODUCTION The discovery of ophiolitic remnants in the geological record is a subject of major interest, not only for tectonic reconstruction of ancient orogenic belts but also to constrain how far back in time modern style plate tectonics has been in operation.

Ophiolites are thought to have formed at mature mid-ocean ridges or back-arc basins, and their lithological succession generally comprises a layer of pillowed basalts, often with interlayered chemical sediments, followed downwards by sheeted dykes, noncumulate gabbro, cumulate gabbro and ultramafic rocks, and tectonized mantle peridotite (Anonymous 1972, Condie 2005). Although relatively well-ordered ophiolite complexes are sometimes preserved in the continents (e.g. Oman, Troodos), most commonly they are considerably disrupted and occur in apparently chaotic terrains.

In contrast with the idealized section of the oceanic lithosphere suggested for several ophiolite complexes, the Alpine-Apennine ophiolites have anomalous lithological successions. Among other features (Rampone \& Piccardo 2000, Piccardo 2003, Muntener \&

1 - Instituto de Geociências, UNICAMP, Campinas (SP), Brasil. E-mail: elson@ige.unicamp.br, juliana.bueno@ige.unicamp.br

2 - Instituto de Geociências, UnB, Brasília (DF), Brasil. E-mail: escayola@unsa.edu.ar

3 - Depart. de Geologia e Pós-Graduação em Geodinâmica e Geofísica, UFRN, Natal (RN), Brasil. E-mail: zorano@geologia.ufrn.br

4 - Instituto de Geociências, UNICAMP, Campinas (SP), Brasil. E-mail: marcelusglaucus@petrobras.com.br

5 - Department of Geology and Geophysics, UWA, Australia. E-mail: nmcnaugh@cyllene.uwa.edu.au 
Piccardo 2003), (i) MORB-type gabbroic rocks are intruded into mantle peridotites and (ii) serpentinized mantle peridotites are directly covered by MORB lava and oceanic sediments, which characterize the steps of rifting during transition from passive lithosphere extension to active oceanic drifting.

Here, we present field relationships and geochemical signatures of chromite-rich peridotites and as- sociated mafic rocks of the Santa Luz ultramafic complex, and discuss the implication for the early evolution of the Rio Itapicuru greenstone belt.

GEOLOGICAL SETTING The Santa Luz peridotite complex, also known in the literature as the Pedra Preta basic-ultrabasic complex (Carvalho Filho et al. 1986, Oliveira \& Knauer 1993), crops out 2 km east of

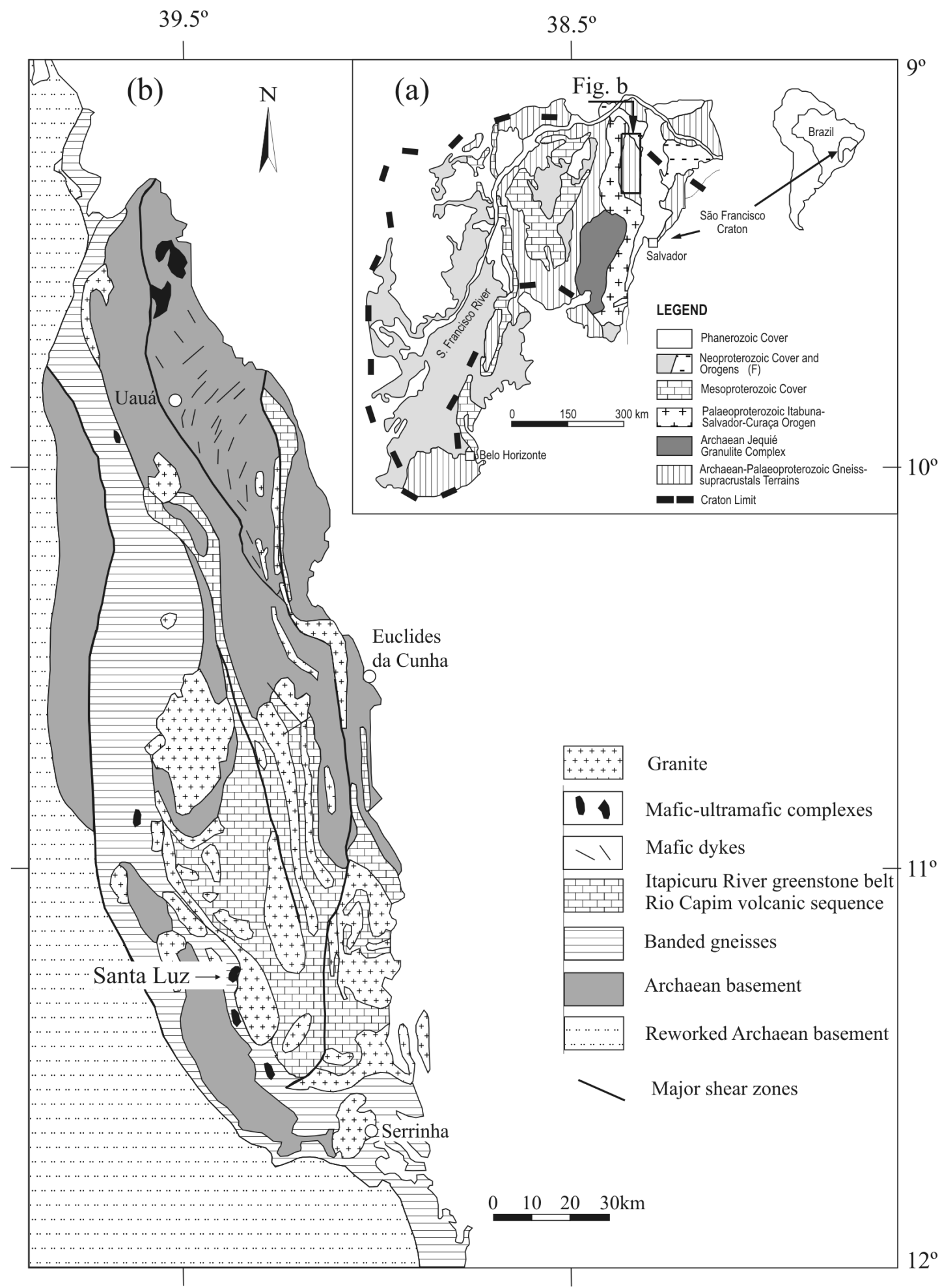

Figure 1 - Northern segment of the Itabuna-Salvador-Curaçá orogen and location of peridotite complexes. Modified after Souza et al. (2003) and Oliveira et al. (2004). 


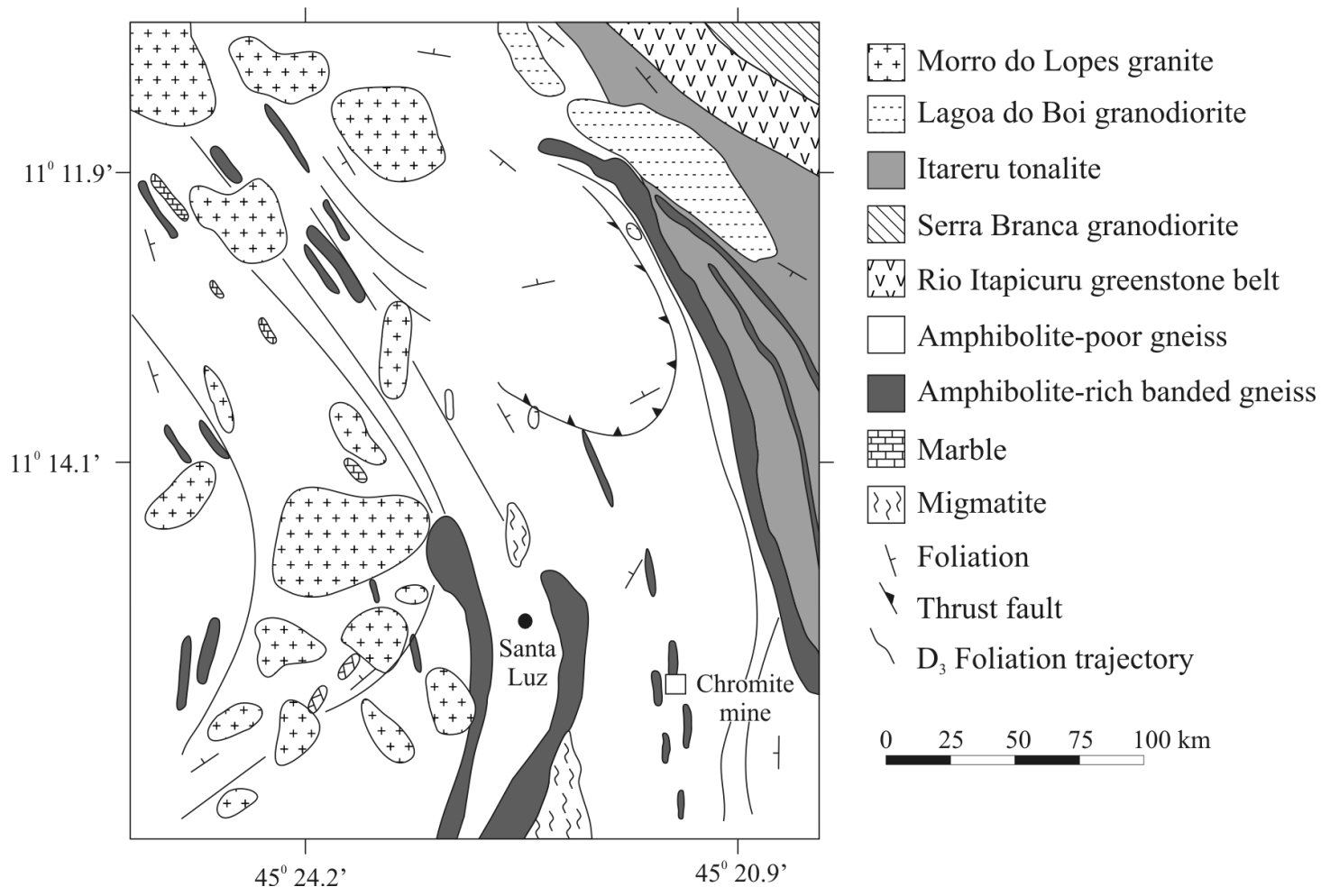

Figure 2 - Geological map of the Santa Luz area. Modified after Oliveira et al. (2002).

the Santa Luz city, Bahia, and is one of several minor peridotite occurrences bordering the Palaeoproterozoic Rio Itapicuru greenstone belt (Figs. 1 e 2). It is economically important because of the high-quality refractory chromite exploited since the Second World War. Currently, Magnesita S.A. holds the right of mineral exploitation.

The complex is a small body (about $400 \mathrm{~m}$ long and $100 \mathrm{~m}$ wide) conformably interleaved with NWtrending, tightly folded, nearly upright banded gneisses composed of decimetre- to a few metre-thick bands of amphibolite and felsic gneisses. Regional geological mapping at the 1: 25000 scale revealed that these banded gneisses are the products of deformation of Archaean grey gneisses intruded by much younger mafic dykes. The contact between the regional gneisses and the ultramafic body is tectonic and marked by narrow shear zones, at places enriched in biotite-phlogopite; the ultramafic rocks may have been folded along with the host gneisses to account for minor occurrences of serpentinite within the latter. Although the rocks are highly weathered in the open-pit mine, drill-core samples reveal that the complex is chiefly composed of serpentinite and serpentinized harzburgite with disseminated and massive chromite. Quartz veins, aplites, pegmatites and mafic dykes crosscut these rocks. Fractures and shear zones are common in the peridotites and are usually associated with alteration of the ultramafic rocks into dark mica and tremolite-rich bands.

The Archaean basement rocks of the Santa Luz region are poly-deformed and represented by grey gneisses and migmatites of the Retirolândia block (3085-2998 Ma; Oliveira et al. 2004). A swarm of ma- fic dykes intruded these gneisses, especially along the eastern part of the block. In the more preserved portions, the migmatites present a steeply dipping, NEtrending foliation parallel to mafic dykes and Archaean gneiss. In some outcrops, the dykes are tightly folded and conformably interleaved with the host Archaean gneisses, but elsewhere the original discordant relationship is preserved.

Coarse-grained gneisses (deformed porphyritic granites), garnet-bearing paragneisses, white marbles, calc-silicate gneisses and quartzites also occur in the Santa Luz region, although their relationships with the Archaean gneisses is not clear.

The entire rock sequence underwent at least four ductile deformation phases. Intrafolial recumbent folds (axis oriented E-W or NW-SE) affecting decimetre-size pegmatite neossomes within banded gneisses register the first event $\left(D_{1}\right)$, which is possibly younger than the one encountered in the Archaean gneisses. The second deformation $\left(\mathrm{D}_{2}\right)$ formed the most penetrative foliation in the region. Strongly stretched granite- to trondhjemite neossomes, recrystallization of brown hornblende and garnet (with plagioclase corona) in amphibolites and paragneisses characterize this event. The respective stretching lineation $\left(1_{2}\right)$ is of low angle and oriented in the WNW-ESE $\left(270\right.$ to $\left.330^{\circ} \mathrm{Az}\right)$ direction. The third event $\left(\mathrm{D}_{3}\right)$ controls the regional structure through inverted antiformes and synformes with axial plane $\left(\mathrm{S}_{3}\right)$ directed N-S to NNW-SSE and fold axis and stretching lineation $\left(1_{3}\right)$ with moderate rake (up to $30^{\circ}$ ) dipping to NNW. The superposition between the $\mathrm{D}_{2}$ and $\mathrm{D}_{3}$ events produced interference patterns intermediated between coaxial (ex. in the chromite mine) and boo- 
merang. In the proximity of N-S to NNW-ESE trending dextral ductile shear zones the $\mathrm{S}_{2}$ and $\mathrm{S}_{3}$ fabrics show progressive verticalization. The dextral kinematics continued under brittle conditions opening space for the intrusion of $30-70^{\circ} \mathrm{Az}$ directed granite dykes, aplite and pegmatite dykes. The last event $\left(D_{4}\right)$ is marked by open to gentle folds with vertical axial plane trending E-W, indicating a late $\mathrm{N}-\mathrm{S}$ shortening.

THE SANTA LUZ PERIDOTITE COMPLEX In order to set constraints on the tectonic significance of the Santa Luz peridotite we combined field relationships between the rock types in the open-pit mine with geochronology, mineral chemistry and whole rock geochemistry. We carried out electron microprobe chemical analyses on the massive-type chromitites, SHRIMP $\mathrm{U}-\mathrm{Pb}$ geochronology on zircons from an aplite dyke that cuts a peridotite, whole rock Sm-Nd isotope data of mafic dykes intrusive into the peridotites, and whole rock geochemistry of the mafic dykes and host peridotites.

Field relationships and petrography The most outstanding feature of the Santa Luz peridotite complex is the occurrence of decimetre- to metre-thick dykes, lenses and irregular bodies of coarse- to medium-grained amphibolites intrusive into the serpentinized peridotites or in structural conformity with them (Fig. 3a). The serpentinites are apparently not much deformed but the mafic dykes are clearly foliated (Fig. 3b). The dykes are composed mostly of pale green amphibole, fresh to totally altered plagioclase, diopside and minor epidote and titanite. The mafic dykes and lenses associated with the Santa Luz peridotites differ from metamorphosed dykes of the country rock banded gneisses in the amphibole type. Amphiboles from the former are pale green, whereas from the latter are dark green to brown. At the contact with the host serpentinite, most mafic dykes and gabbroic lenses show a few decimetre-wide band enriched in epidote and zoisite, with minor pale green amphibole, diopside and titanite. This aspect is similar to the metasomatic process of rodingitization described in ocean-floor rocks and in ophiolite complexes worldwide (Bideau et al. 1991, Rösli et al. 1991, Puga et al. 1999). Accordingly, the mantle-derived basic magmas percolate the mantle section of the oceanic lithosphere, as dykes or irregular bodies, and subsequently all rocks undergo ocean-floor metasomatism, converting partially the mantle peridotites into serpentinite and the basic dykes into low grade metamorphic rocks with hydrogarnet-bearing assemblages (rodingite). During such a process, there is a significant amount of element losses and gains, and these features were observed in mafic dykes of the Santa Luz peridotite complex, as briefly commented in the geochemistry section.

Analytical techniques We collected major element data on chromium-rich spinels on a JEOL JXA-8600 microprobe of the Institute of Geosciences of University of São Paulo. Whole rock major and trace element analyses were performed respectively on fusion beads
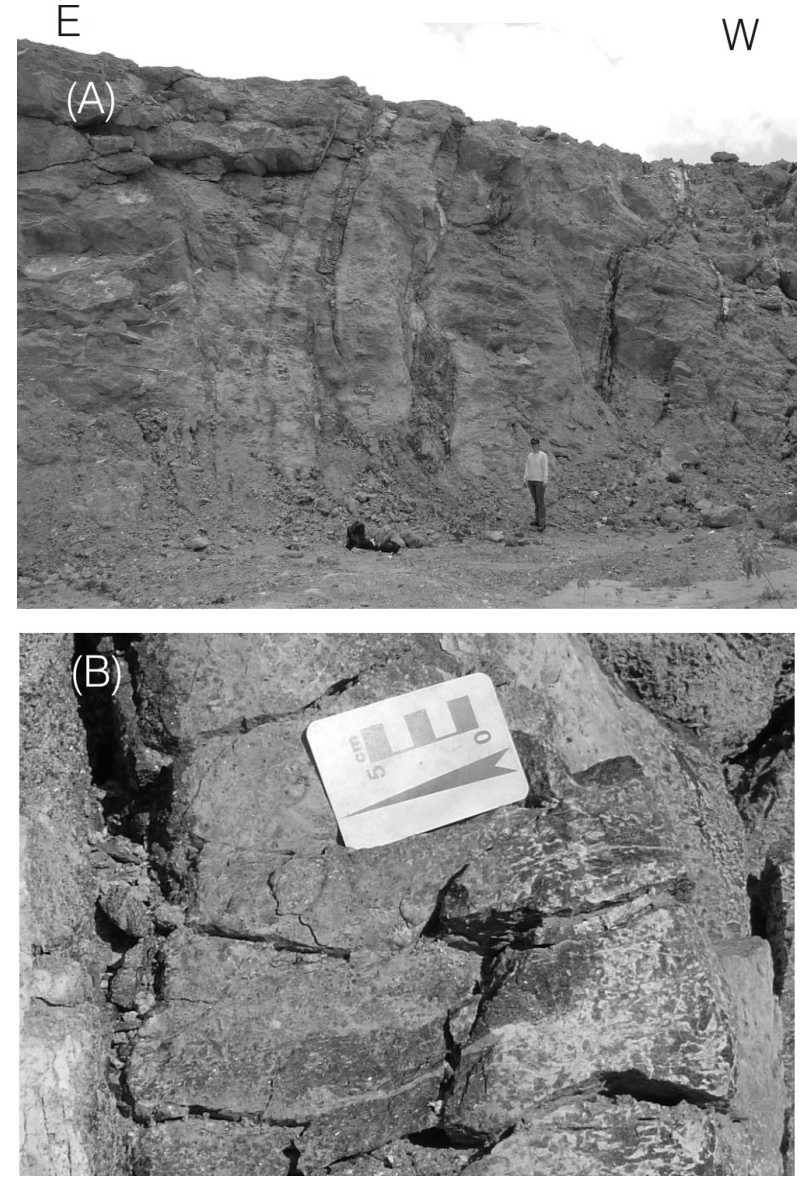

Figure 3 - Mafic dykes intrusive into serpentinites, Santa Luz peridotite complex (A), as evidence for melt impregnation; Detail of a foliated and amphibolitized mafic dyke (B).

and pressed powder pellets at the X-ray fluorescence laboratory of the Geosciences Institute of UNICAMP. The analytical precision is checked against the international reference samples WSE (dolerite) and RGM-1 (rhyolite); for the major and minor elements the instrumental errors are less than $1.2 \%$, whereas for most trace elements except $\mathrm{Th}(7 \%), \mathrm{Pb}(5 \%)$, and $\mathrm{Nb}$ and $\mathrm{Ga}(3 \%)$ the errors are below 1.5\%. Zircon U-Pb SHRIMP data were acquired on the SHRIMP-II laboratory at Perth, Australia, following the operation conditions described by Smith et al. (1998); 7 analyses of the CZ3 standard zircons indicated a $\mathrm{Pb} / \mathrm{U}$ calibration reproducibility $(1 \sigma)$ of $1.42 \%$. Common- $\mathrm{Pb}$ corrections were made assuming Broken Hill common- $\mathrm{Pb}$ compositions for all sample analyses. Pooled ages are quoted at $1 \sigma$ error and dates from analyses that are $<95 \%$ concordant were regarded as minimum ages. Geoanalysis, Perth-Australia, analysed four massive-type chromitites for platinum group element (PGE). Finally, the Sm-Nd isotope data were collected at the Geochronology laboratory of University of Brasilia, according to the protocols of Gioia \& Pimentel (2000).

Geochronology Five representative samples of amphibolite dykes, gabbro lenses, peridotite and an epi- 
dote-rich rock were analysed for $\mathrm{Sm}-\mathrm{Nd}$ isotopes in order to constrain the timing of melt impregnation (data in Table 4). Unfortunately, the data fit in no reasonable isochron.

Nevertheless, a minimum age for the complex is estimated from U-Pb SHRIMP analyses of zircon grains extracted from an aplite dyke intrusive into the peridotite. The results are presented in figure 4 and in table 1.

The amount of zircon grains recovered in the sampled aplite is small; ten grains were analysed but only six are suitable for age calculation. Most of the zircon grains are inherited from the basement (individual ages vary from $3020 \mathrm{Ma}$ to $3145 \mathrm{Ma}$ ) with only two nearlyconcordant grains giving a ${ }^{207} \mathrm{~Pb} /{ }^{206} \mathrm{~Pb}$ age of $2085 \pm 12$ Ma. Although the data is limited, we suggest that the peridotite complex is older than $2085 \mathrm{Ma}$. A felsic portion of the host banded gneiss yields an Archaean U-Pb SHRIMP age (2983 $\pm 8 \mathrm{Ma}$, Oliveira et al. 2004); this

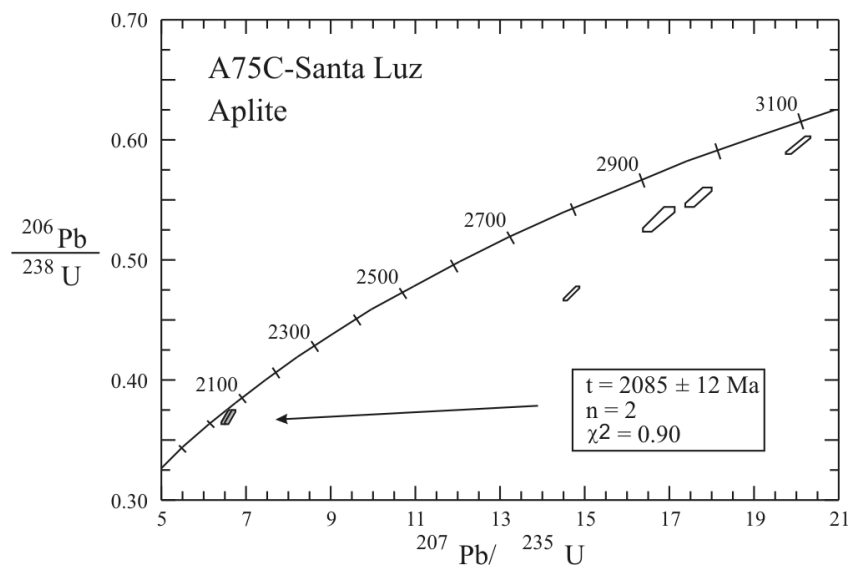

Figure 4 - Zircon SHRIMP U-Pb ages of an aplite intrusive in serpentinite of the Santa Luz peridotite complex. date sets an upper age limit for the ultramafic rocks.

Chemistry of massive-type chromitites Massive and disseminated chromites are ubiquitous in the Santa Luz peridotite complex. The former occurs as disrupted and faulted pods (Carvalho Filho et al. 1986). In this study, we emphasized only the massive chromitites because the disseminated chromites are prone to chemical exchange with associated silicates. In order to assess the extent to which post-magmatic element mobility affected the chromite composition, we carried out a detailed analytical traverse across a euhedral massivetype chromite grain (Fig 5). With the exception of $\mathrm{Cr}$, $\mathrm{Al}$ and $\mathrm{Ti}$ at the very end of a grain rim, no significant element variation is observed in the central portion of the grains. As such, the homogeneous core of chromite grains in the massive chromitites is interpreted as the best estimate of the primary cumulus chromite composition (cf. Eales \& Reynolds 1986, Suita \& Strieder 1996, Spier \& Ferreira Filho 2001, Marques \& Ferreira Filho 2003). Therefore, in the following discussion we consider only spot analyses from the core of individual chromite grains.

Representative microprobe data of chromite grains are in Table 2 and the chemical variation of the full data set is shown in figure 6 .

In several diagram like those of figure 6 , the Santa Luz chromites plot in the ophiolite or Alpine peridotite field, although an unequivocal distinction from layered complexes is not always possible. As an additional evidence in support of our interpretation that the core of chromite grains closely approach the original igneous composition, the studied chromite grains do not show a trend towards iron enrichment, a characteristic of metamorphosed chromite (e.g. Suita \& Strieder 1996). The high $\mathrm{Cr}^{*}(\mathrm{Cr} / \mathrm{Cr}+\mathrm{Al})$ values of the Santa Luz chromites $\left(\mathrm{Cr}^{*}=0.60-0.70\right)$ imply a high percentage of melt extraction from a mantle harzbugite, according to the algorithm of Hellebrand et al. (2001).

Platinum group element (PGE) analyses of

Table 1 - SHRIMP U-Pb data on zircons from a pegmatite intrusive into serpentine of the Santa Luz Peridotite Complex.

\begin{tabular}{|c|c|c|c|c|c|c|c|c|c|c|c|c|c|c|c|c|c|}
\hline \multirow{3}{*}{$\begin{array}{c}\text { grain- } \\
\text { spot }\end{array}$} & \multirow{3}{*}{$\begin{array}{c}\mathrm{U} \\
(\mathrm{ppm})\end{array}$} & \multirow{3}{*}{$\begin{array}{c}\text { Th } \\
(\mathrm{ppm})\end{array}$} & \multirow{3}{*}{$\frac{T h}{U}$} & \multirow{3}{*}{$\begin{array}{c}4 \mathrm{f} 206 \\
(\%)\end{array}$} & \multicolumn{3}{|c|}{ 204-corrected--> } & \multirow{3}{*}{$+/-$} & \multirow{3}{*}{$\frac{206^{*}}{238^{*}}$} & \multirow{3}{*}{$+/-$} & \multirow{3}{*}{$\frac{207^{*}}{235^{*}}$} & \multirow{3}{*}{$+/-$} & \multirow{3}{*}{$\frac{208^{*}}{232^{*}}$} & \multirow{3}{*}{$+/-$} & \multirow{2}{*}{\multicolumn{3}{|c|}{$\frac{207^{*}}{206^{*}}$}} \\
\hline & & & & & \multirow{2}{*}{$\frac{207^{*}}{206^{*}}$} & \multirow{2}{*}{$+/-$} & \multirow{2}{*}{$\frac{208^{*}}{206^{*}}$} & & & & & & & & & & \\
\hline & & & & & & & & & & & & & & & $\%$ conc & Age (Ma) & $+/-$ \\
\hline $1-1$ & 117 & 42 & 0.361 & 0.26 & 0.232 & 0.0018 & 0.1049 & 0.0022 & 0.5546 & 0.0079 & 17.7383 & 0.3015 & 0.1611 & 0.0043 & 93 & 3066 & 12 \\
\hline $1-2$ & 141 & 56 & 0.395 & 0.10 & 0.244 & 0.0009 & 0.1059 & 0.0011 & 0.5978 & 0.0076 & 20.1003 & 0.2744 & 0.1602 & 0.0028 & 96 & 3145 & 6 \\
\hline $2-1$ & 197 & 86 & 0.437 & 0.42 & 0.2254 & 0.0010 & 0.1529 & 0.0016 & 0.4736 & 0.0057 & 14.7171 & 0.1955 & 0.1656 & 0.0028 & 83 & 3020 & 7 \\
\hline $3-1$ & 25 & 1 & 0.026 & 0 & 0.2274 & 0.0022 & 0.0087 & 0.0006 & 0.5352 & 0.0103 & 16.7835 & 0.3824 & 0.1793 & 0.0137 & 91 & 3034 & 16 \\
\hline $4-1$ & 187 & 1 & 0.003 & 0.06 & 0.1284 & 0.0009 & 0.0018 & 0.0012 & 0.3697 & 0.0059 & 6.54440 & 0.1203 & 0.2018 & 0.1277 & 98 & 2076 & 13 \\
\hline $7-1$ & 243 & 21 & 0.086 & 0.19 & 0.1301 & 0.0012 & 0.0218 & 0.0010 & 0.3693 & 0.0062 & 6.62490 & 0.1318 & 0.0929 & 0.0046 & 97 & 2099 & 16 \\
\hline
\end{tabular}



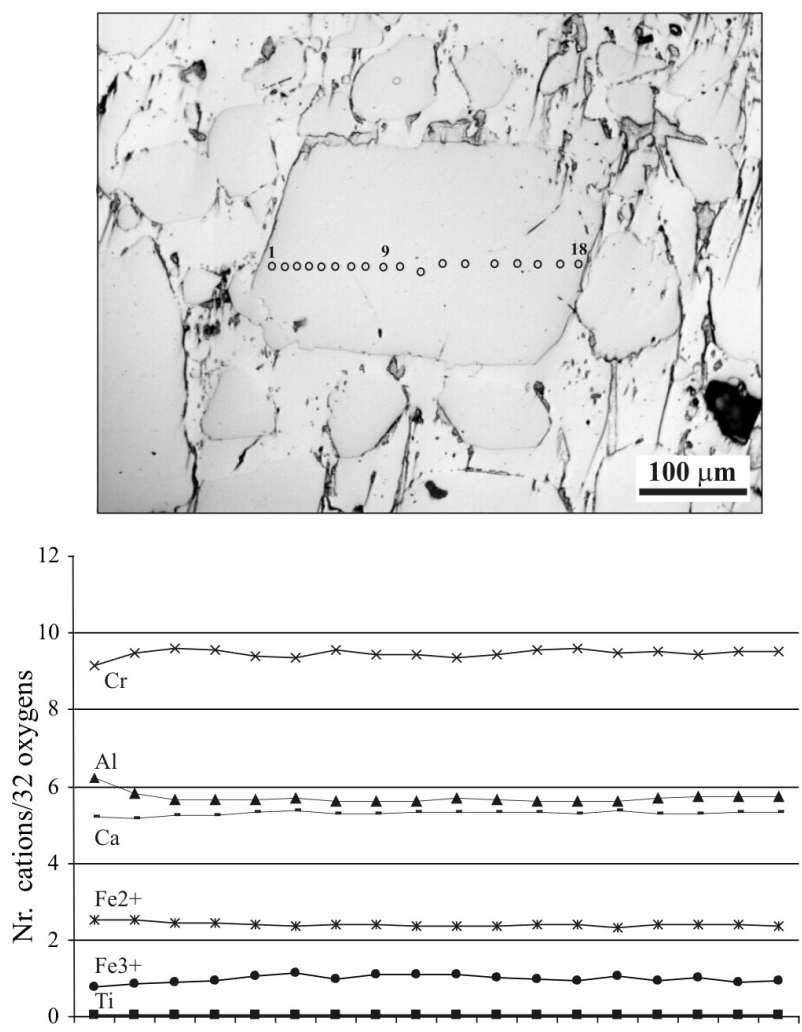

Figure 5 - Electron microprobe analyses across a chromite grain showing weak zoning of $\mathrm{Al}, \mathrm{Cr}$ and $\mathrm{Fe}^{3+}$ at the rim. Analytical data are listed in Table 2.

massive chromitites are in table 3 and figure 7. The chondrite normalized PGE patterns (Fig. 7) are similar to chromitites with very low sulphide contents such as those from ophiolite complexes and from the lower layers of the Critical Zone (LG-1) of the Bushveld layered complex (Von Gruenewaldt \& Merkle 1995). The studied chromitites bear no similarity with chromitites with sulphide inclusions, as the UG-2 chromitites from the Bushveld complex.

Geochemistry of the mafic rocks The samples that underwent a large extent of metasomatism, such as the epidote-rich dyke margins are depleted in $\mathrm{Na}_{2} \mathrm{O}$ and enriched in $\mathrm{CaO}$, and follow the rodingite trend in figure 8. In general, the least metasomatized, fine- to coarse-grained amphibolite dykes have geochemical characteristics comparable to continental tholeiites and transitional-type MORB, and are slightly more primitive than similar dykes associated to the regional gneisses (Table 4). The silica contents of the former (41.98-47.09 $\mathrm{wt} \%$ ) fall in the range of picritic basalts to basalts with low $\mathrm{TiO}_{2}$ abundances $(0.2-0.8 \mathrm{wt} \%)$. The incompatible element ratios $\mathrm{Zr} / \mathrm{Y}(1.4-2.9), \mathrm{Y} / \mathrm{Nb}$ (4-14.2), Zr/Nb (14-18), Ti/Y (110-178), Ti/Zr (62-80) and Ti/V (13-20) are similar to either T-MORB (Floyd 1989), low-Ti continental flood basalts (Hergt et al. 1991, Peate 1997) and continental mafic dykes (Olivei- ra et al. 1990, Bellieni et al. 1995).

The negative $\mathrm{Nb}$ anomaly on mantle-normalized, multi-element diagramme (Fig. 9) indicates a significant crustal signature. The $\mathrm{CaO}$-rich samples show high-field strength element (HFSE) abundances similar to the other amphibolite dykes but significantly lower values of lowfield strength elements (LFSE). On the other hand, sample $\mathrm{K}$ from this dyke group has undergone both LFSE and HFSE depletion, especially $\mathrm{Zr}$ and Ti.

DISCUSSION Field relationships, rock association and the geochemical characteristics of massive chromitites and amphibolite dykes/lenses are the evidences we present to support the interpretation that the Santa Luz peridotite complex is similar to ophiolitic complexes found in the Alpine-Apennine orogenic belts. The ophiolites in these belts are anomalous with respect to the idealized ophiolite pseudo-stratigraphy which comprises ultramafic rocks at the base, with variable amounts of harzburgite, lherzolite and dunite (commonly serpentinized), overlain by layered/non-layered gabbros, then by a sheeted dyke complex and basic volcanic rocks with a cover of deep-sea sediments (Anonymous 1972, Coleman 1977). The Alpine-type peridotites comprise mantle peridotites intruded by MORB-type gabbroic rocks; MORB lava flows and oceanic sediments may directly cover serpentinized mantle peridotites (Rampone \& Piccardo 2000). This type of ophiolite is named "transitional ophiolites" (Kusky 2004, Windley 2005), and its formation may have taken place at oceancontinent transitions of a magma-poor rifted margin (Wilson et al. 2001, Manatschal 2004). This type of rifted continental margin is one of the three classes recognised: volcanic, magma-poor and strike-slip. The former is characterized by voluminous emplacements of predominantly mafic rocks which do not originate at normal seafloor spreading centers, such as those off East Greenland, Norway, and the South Atlantic rifted margins at the Rio Grande and Walvis ridges (Gladczenko et al. 1997). Strike-slip margins are typified by the Cote D'Ivore-Ghana margin and are marked by a sharp transition between thinned continental crust and an adjacent oceanic crust; the transition is underlined by a marginal ridge with a steep continental slope (Mascle et al. 1995). Magma-poor continental margins, on the other hand, are characterized by thinned continental crust dissected by low-angle detachment faults, with oceanward increasing of mafic melt volumes, that merges into oceanic crust (e.g. Whitmarsh et al. 2001, Wilson et al. 2001). According to Whitmarsh et al. (2001), during the rifting stage of a magma-poor continental margin the lithosphere extends and thins, the lithospheric mantle exhumes to the seafloor and the upwelling asthenosphere undergoes partial melting by adiabatic decompression; the zone of exhumed continental mantle evolves oceanward into seafloor spreading with increasing magmatic activity.

The present-day analogues of the transitional-type ophiolites lie offshore the Iberia continental margin (Whitmarsh et al. 2001, Wilson et al. 
Table 2 - Representative chemical analyses of cores of chromite grains from massive chromitites of the Santa Luz Peridotite Complex. Analytical data for the chemical traverse of Fig. 5 are listed as SL-01.

\begin{tabular}{|c|c|c|c|c|c|c|c|c|c|c|c|c|c|c|c|c|c|c|c|c|c|c|c|}
\hline Sample \# & $\begin{array}{l}\text { SL } \\
02\end{array}$ & $\begin{array}{l}\text { SL } \\
02\end{array}$ & $\begin{array}{l}\text { SL } \\
02\end{array}$ & $\begin{array}{l}\text { SL } \\
02\end{array}$ & $\begin{array}{l}\text { SL } \\
02\end{array}$ & $\begin{array}{l}\text { SL } \\
01\end{array}$ & $\begin{array}{l}\text { SL } \\
01\end{array}$ & $\begin{array}{l}\text { SL } \\
01\end{array}$ & $\begin{array}{l}\text { SL } \\
01\end{array}$ & $\begin{array}{l}\text { SL } \\
01\end{array}$ & $\begin{array}{l}\text { SL } \\
01\end{array}$ & $\begin{array}{l}\text { SL } \\
01\end{array}$ & $\begin{array}{l}\text { SL } \\
01\end{array}$ & $\begin{array}{l}\text { SL } \\
01\end{array}$ & $\begin{array}{l}\text { SL } \\
01\end{array}$ & $\begin{array}{l}\text { SL } \\
01\end{array}$ & $\begin{array}{l}\text { SL } \\
01\end{array}$ & $\begin{array}{l}\text { SL } \\
01\end{array}$ & $\begin{array}{l}\text { SL } \\
01\end{array}$ & $\begin{array}{l}\text { SL } \\
01\end{array}$ & $\begin{array}{l}\text { SL } \\
01\end{array}$ & $\begin{array}{l}\text { SL } \\
01\end{array}$ & $\begin{array}{l}\text { SL } \\
01\end{array}$ \\
\hline grain & 3 & 8 & 10 & 13 & 21 & 1 & 2 & 3 & 4 & 5 & 6 & 7 & 8 & 9 & 10 & 11 & 12 & 13 & 14 & 15 & 16 & 17 & 18 \\
\hline $\mathrm{SiO}_{2}$ & 0.00 & 0.00 & 0.00 & 0.01 & 0.00 & 0.06 & 0.05 & 0.00 & 0.01 & 0.01 & 0.00 & 0.00 & 0.01 & 0.00 & 0.05 & 0.02 & 0.03 & 0.02 & 0.02 & 0.00 & 0.01 & 0.04 & 0.01 \\
\hline $\mathrm{TiO}_{2}$ & 0.24 & 0.25 & 0.18 & 0.28 & 0.29 & 0.17 & 0.16 & 0.15 & 0.18 & 0.20 & 0.16 & 0.24 & 0.21 & 0.22 & 0.21 & 0.17 & 0.22 & 0.11 & 0.21 & 0.13 & 0.16 & 0.19 & 0.18 \\
\hline $\mathrm{Al}_{2} \mathrm{O}_{3}$ & 15.27 & 16.76 & 18.75 & 18.76 & 19.11 & 21.10 & 19.83 & 19.52 & 19.47 & 19.49 & 19.46 & 19.28 & 19.38 & 19.21 & 19.39 & 19.38 & 19.31 & 19.47 & 19.35 & 19.49 & 19.58 & 19.48 & 19.62 \\
\hline $\mathrm{Cr}_{2} \mathrm{O}_{3}$ & 52.79 & 50.67 & 48.65 & 49.95 & 49.26 & 46.44 & 47.99 & 49.28 & 49.20 & 48.22 & 47.49 & 49.00 & 48.39 & 47.88 & 47.60 & 48.18 & 49.17 & 49.45 & 48.72 & 48.65 & 48.18 & 48.29 & 48.58 \\
\hline $\mathrm{FeOT}$ & 17.79 & 17.20 & 16.84 & 16.87 & 16.62 & 15.46 & 16.01 & 16.01 & 16.25 & 16.47 & 16.38 & 16.16 & 16.65 & 16.31 & 16.38 & 16.12 & 16.14 & 16.11 & 16.15 & 15.87 & 16.10 & 15.57 & 15.72 \\
\hline $\mathrm{MnO}$ & 0.74 & 0.68 & 0.71 & 0.74 & 0.72 & 0.00 & 0.00 & 0.00 & 0.00 & 0.00 & 0.00 & 0.00 & 0.00 & 0.00 & 0.00 & 0.00 & 0.00 & 0.00 & 0.00 & 0.00 & 0.00 & 0.00 & 0.00 \\
\hline $\mathrm{MgO}$ & 12.20 & 12.85 & 13.38 & 12.21 & 12.92 & 13.98 & 13.89 & 14.27 & 14.35 & 14.45 & 14.43 & 14.41 & 14.42 & 14.41 & 14.37 & 14.43 & 14.50 & 14.50 & 14.65 & 14.36 & 14.35 & 14.32 & 14.43 \\
\hline $\mathrm{CaO}$ & 0.00 & 0.02 & 0.02 & 0.02 & 0.00 & 0.03 & 0.00 & 0.02 & 0.02 & 0.00 & 0.00 & 0.00 & 0.03 & 0.00 & 0.02 & 0.01 & 0.01 & 0.01 & 0.02 & 0.01 & 0.01 & 0.02 & 0.05 \\
\hline $\mathrm{ZnO}$ & 0.14 & 0.11 & 0.05 & 0.04 & 0.04 & 0.00 & 0.03 & 0.05 & 0.01 & 0.02 & 0.07 & 0.11 & 0.07 & 0.09 & 0.09 & 0.04 & 0.08 & 0.01 & 0.06 & 0.04 & 0.12 & 0.02 & 0.05 \\
\hline $\mathrm{NiO}$ & 0.14 & 0.18 & 0.17 & 0.22 & 0.16 & 0.21 & 0.16 & 0.17 & 0.21 & 0.18 & 0.16 & 0.21 & 0.17 & 0.17 & 0.19 & 0.18 & 0.21 & 0.13 & 0.19 & 0.23 & 0.17 & 0.18 & 0.19 \\
\hline Total & 99.31 & 98.72 & 98.76 & 99.09 & 99.13 & 97.45 & 98.12 & 99.47 & 99.70 & 99.03 & 98.15 & 99.41 & 99.33 & 98.29 & 98.31 & 98.53 & 99.66 & 99.81 & 99.35 & 98.77 & 98.69 & 98.11 & 98.84 \\
\hline $\mathrm{O}$ & 32.00 & 32.00 & 32.00 & 32.00 & 32.00 & 32.00 & 32.00 & 32.00 & 32.00 & 32.00 & 32.00 & 32.00 & 32.00 & 32.00 & 32.00 & 32.00 & 32.00 & 32.00 & 32.00 & 32.00 & 32.00 & 32.00 & 32.00 \\
\hline $\mathrm{Si}$ & 0.00 & 0.00 & 0.00 & 0.00 & 0.00 & 0.01 & 0.01 & 0.00 & 0.00 & 0.00 & 0.00 & 0.00 & 0.00 & 0.00 & 0.01 & 0.01 & 0.01 & 0.01 & 0.01 & 0.00 & 0.00 & 0.01 & 0.00 \\
\hline $\mathrm{Ti}$ & 0.05 & 0.05 & 0.03 & 0.05 & 0.05 & 0.03 & 0.03 & 0.03 & 0.03 & 0.04 & 0.03 & 0.04 & 0.04 & 0.04 & 0.04 & 0.03 & 0.04 & 0.02 & \begin{tabular}{|l|}
0.04 \\
\end{tabular} & 0.02 & 0.03 & 0.04 & 0.03 \\
\hline $\mathrm{Al}$ & 4.61 & 5.03 & 5.55 & 5.59 & 5.65 & 6.20 & 5.83 & 5.67 & 5.64 & 5.67 & 5.71 & 5.60 & 5.63 & 5.63 & 5.68 & 5.67 & 5.59 & 5.63 & 5.61 & 5.69 & 5.72 & 5.72 & 5.72 \\
\hline $\mathrm{Cr}$ & 10.68 & 10.20 & 9.67 & 9.99 & 9.78 & 9.16 & 9.47 & 9.60 & 9.56 & 9.41 & 9.34 & 9.55 & 9.43 & 9.42 & 9.36 & 9.45 & 9.56 & 9.59 & 9.48 & 9.53 & 9.44 & 9.51 & 9.50 \\
\hline $\mathrm{Fe}^{2+}$ & 3.22 & 3.01 & 2.86 & 3.28 & 3.05 & 2.51 & 2.54 & 2.45 & 2.44 & 2.39 & 2.35 & 2.40 & 2.40 & 2.36 & 2.38 & 2.37 & 2.39 & 2.41 & 2.33 & 2.38 & 2.39 & 2.40 & 2.37 \\
\hline $\mathrm{Fe}^{3+}$ & 0.59 & 0.65 & 0.68 & 0.29 & 0.44 & 0.76 & 0.84 & 0.90 & 0.95 & 1.07 & 1.12 & 0.98 & 1.09 & 1.10 & 1.09 & 1.03 & \begin{tabular}{|l|}
0.98 \\
\end{tabular} & 0.95 & 1.04 & 0.95 & 1.00 & 0.90 & 0.93 \\
\hline $\mathrm{Mn}$ & 0.16 & 0.15 & 0.15 & 0.16 & 0.15 & 0.00 & 0.00 & 0.00 & 0.00 & 0.00 & 0.00 & 0.00 & 0.00 & 0.00 & 0.00 & 0.00 & 0.00 & 0.00 & 0.00 & 0.00 & 0.00 & 0.00 & 0.00 \\
\hline $\mathrm{Mg}$ & 4.65 & 4.88 & 5.01 & 4.60 & 4.84 & 5.20 & 5.17 & 5.24 & 5.26 & 5.32 & 5.35 & 5.30 & 5.30 & 5.35 & 5.33 & 5.34 & 5.31 & 5.30 & 5.37 & 5.30 & 5.30 & 5.32 & 5.32 \\
\hline $\mathrm{Ca}$ & 0.00 & 0.01 & 0.01 & 0.01 & 0.00 & 0.01 & 0.00 & 0.01 & 0.01 & 0.00 & 0.00 & 0.00 & 0.01 & 0.00 & 0.00 & 0.00 & 0.00 & 0.00 & 0.00 & 0.00 & 0.00 & 0.00 & 0.01 \\
\hline $\mathrm{Zn}$ & 0.03 & 0.02 & 0.01 & 0.01 & 0.01 & 0.00 & 0.01 & 0.01 & 0.00 & 0.00 & 0.01 & 0.02 & 0.01 & 0.02 & 0.02 & 0.01 & 0.01 & 0.00 & 0.01 & 0.01 & 0.02 & 0.00 & 0.01 \\
\hline $\mathrm{Ni}$ & 0.03 & 0.04 & 0.03 & 0.04 & 0.03 & 0.04 & 0.03 & 0.03 & 0.04 & 0.04 & 0.03 & 0.04 & 0.03 & 0.03 & 0.04 & 0.04 & 0.04 & 0.02 & 0.04 & 0.05 & 0.03 & 0.04 & 0.04 \\
\hline Total & 24.01 & 24.02 & 24.01 & 24.01 & 24.01 & 23.93 & 23.93 & 23.94 & 23.94 & 23.94 & 23.95 & 23.94 & 23.94 & 23.94 & 23.94 & 23.94 & 23.94 & 23.94 & 23.94 & 23.94 & 23.94 & 23.94 & 23.94 \\
\hline $\mathrm{Cr} /(\mathrm{Cr}+\mathrm{Al})$ & 0.70 & 0.67 & 0.64 & 0.64 & 0.63 & 0.60 & 0.62 & 0.63 & 0.63 & 0.62 & 0.62 & 0.63 & 0.63 & 0.63 & 0.62 & 0.63 & 0.63 & 0.63 & 0.63 & 0.63 & 0.62 & 0.62 & 0.62 \\
\hline $\mathrm{Mg} /(\mathrm{Mg}+\mathrm{Fe})$ & 0.59 & 0.62 & 0.64 & 0.58 & 0.61 & 0.67 & 0.67 & 0.68 & 0.68 & 0.69 & 0.69 & 0.69 & 0.69 & 0.69 & 0.69 & 0.69 & \begin{tabular}{|l|}
0.69 \\
\end{tabular} & 0.69 & 0.70 & 0.69 & \begin{tabular}{|l|}
0.69 \\
\end{tabular} & 0.69 & \begin{tabular}{|l}
0.69 \\
\end{tabular} \\
\hline
\end{tabular}

2001, Piccardo 2003), at the Southwest Australian passive margin (Beslier et al. 1999, 2004) and probably in the island of Zabargad, Northern Red Sea (Bonatti et al. 1983, Nicolas et al. 1987). In the intensively studied Iberia continental margin a zone of exhumed sub-continental lithospheric mantle contains diffuse and thin sheets of amphibole-diorites, weakly deformed gabbros and pyroxenites, and late-stage T-MORB to continental dolerite dykes (Chazot et al. 2005). In the Zabargad island, although there is a considerable debate about the peridotites ages, i.e. whether Neoproterozoic or Miocene, or both (Snow \& Schmidt 1999), basaltic dykes cut mantle peridotites and continental gneisses. The geochemistry of the basaltic dykes is similar to basalts from the transition between distensive continental mar- 

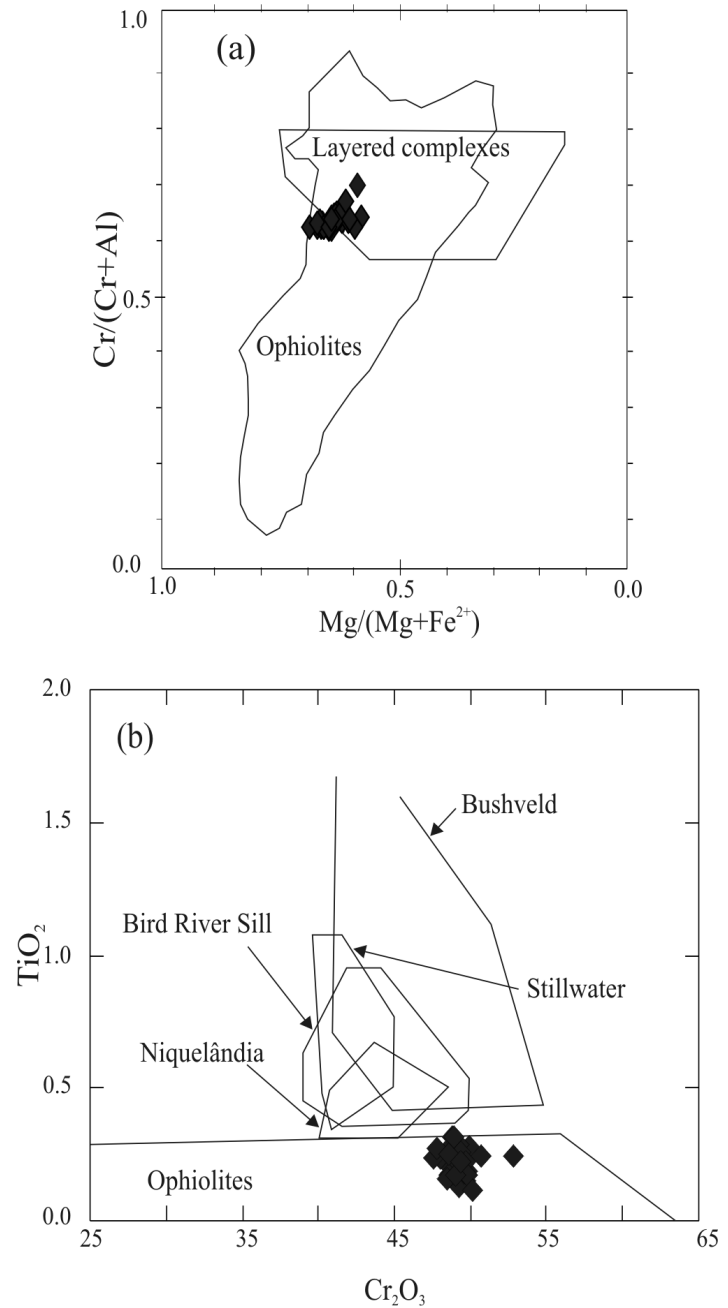

Figure 6 - Major element diagrammes for massive-type chromites of the Santa Luz peridotite complex. Data from this work and from Araújo (1998). Fields in (a) and (b) are respectively from Dick \& Bullen (1984) and Suita \& Strieder (1996).

Table 3 - Platinum group element data for massive chromitites from the Santa Luz Peridotite Complex.

\begin{tabular}{l|c|c|c|c|c|c}
\hline & $\begin{array}{c}\text { Os } \\
(\mathrm{ppb})\end{array}$ & $\begin{array}{c}\mathrm{Ir} \\
(\mathrm{ppb})\end{array}$ & $\begin{array}{c}\mathrm{Ru} \\
(\mathrm{ppb})\end{array}$ & $\begin{array}{c}\mathrm{Rh} \\
(\mathrm{ppb})\end{array}$ & $\begin{array}{c}\mathrm{Pt} \\
(\mathrm{ppb})\end{array}$ & $\begin{array}{c}\mathrm{Pd} \\
(\mathrm{ppb})\end{array}$ \\
\hline AM2-A & 90 & 118 & 265 & 17 & 20 & 8 \\
\hline AM2-B & 94 & 120 & 270 & 17 & 18 & 10 \\
\hline $\begin{array}{l}\text { SLM04- } \\
\text { 2W }\end{array}$ & 56 & 54 & 210 & 20 & 32 & 64 \\
\hline $\begin{array}{l}\text { SLM04- } \\
\text { 4W }\end{array}$ & 62 & 74 & 200 & 17 & 6 & 4 \\
\hline
\end{tabular}

gins and ocean floor (Petrini et al. 1988).

A similar scenario is envisaged for the Santa Luz peridotite and associated mafic dykes, as well as

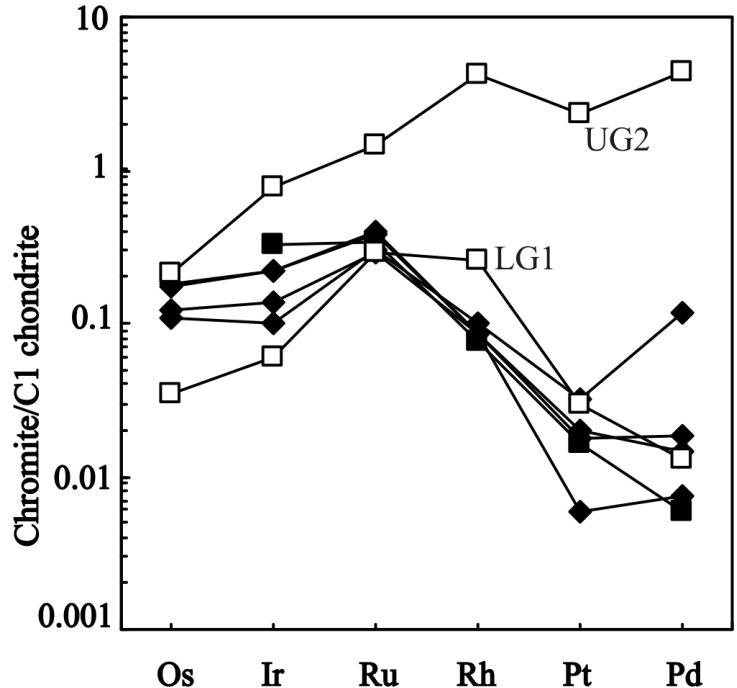

Figure 7 - Chondrite-normalized platinum group elements for massive-type chromitites from the Santa Luz peridotite complex (diamonds) compared with chromitites from ophiolite complex (filled square) and layered intrusion (Bushveld UG2 and LG1, open square). Data after Mathez \& Peach (1989) and Von Gruenewaldt \& Merkle (1995). Chondrite abundances after Naldrett \& Duke (1980).

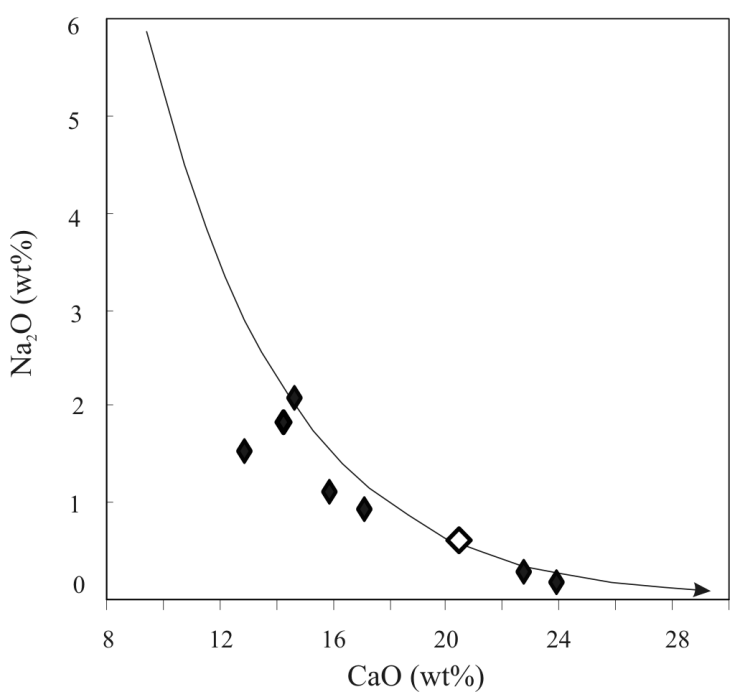

Figure 8 - $\mathrm{CaO}$ vs $\mathrm{Na}_{2} \mathrm{O}$ plot for mafic rocks intrusive into the Santa Luz peridotites, illustrating the chemical changes during epidotization at dyke margin. Rodingite trend and average (open diamond) after Puga et al. (1999).

for the regional gneisses intruded by mafic dykes and later deformed and metamorphosed. In a previous publication (Oliveira et al. 2005), we suggested that the mafic dykes associated to the banded gneisses and to the peridotite complex could be much younger and unrelated to the peridotites. However, given the different 
Table 4 - Whole rock major and trace element data, and Sm-Nd isotope data of representative rocks from the Santa Luz Peridotite Complex. * rodingites after Puga et al. (1999); na - not analysed.

\begin{tabular}{|c|c|c|c|c|c|c|c|c|c|}
\hline Sample & M1 & M2 & $\mathrm{N}$ & $\mathrm{J}$ & K & $\mathrm{O}$ & $\begin{array}{l}\text { SLB101EB } \\
\text { drill-core }\end{array}$ & $\begin{array}{c}\text { average } \\
\text { regional dykes }\end{array}$ & $\begin{array}{c}\text { average } \\
\text { rodingites* }\end{array}$ \\
\hline \multirow{2}{*}{ Rock type } & amphibolite & amphibolite & rodingite? & gabbro & rodingite? & serpentinite & rodingitic & amphibolite & $\mathrm{n}=27$ \\
\hline & dyke & dyke & \multicolumn{2}{|c|}{ (margin M2) } & $($ margin $\mathrm{J})$ & (close to M2) & amphibolite & $\mathrm{n}=16$ & \\
\hline $\mathrm{SiO}_{2}$ & 46.42 & 41.98 & 45.88 & 47.09 & 45.42 & 43.42 & 45.21 & 49.53 & 39.62 \\
\hline $\mathrm{TiO}_{2}$ & 0.82 & 0.859 & 0.563 & 0.283 & 0.207 & 0.067 & 0.75 & 1.24 & 1.96 \\
\hline $\mathrm{Al}_{2} \mathrm{O}_{3}$ & 13.9 & 15.36 & 13.22 & 16.16 & 12.78 & 1.63 & 14.10 & 14.78 & 14.56 \\
\hline $\mathrm{Fe}_{2} \mathrm{O}_{3}$ & 10.57 & 11.9 & 7.57 & 7.94 & 6.89 & 7.35 & 9.94 & 13.68 & 10.75 \\
\hline $\mathrm{MnO}$ & 0.246 & 0.209 & 0.313 & 0.14 & 0.227 & 0.069 & 0.22 & 0.2 & 0.21 \\
\hline $\mathrm{MgO}$ & 9.69 & 9.87 & 7.9 & 10.09 & 8.23 & 21.41 & 8.98 & 6.7 & 8.88 \\
\hline $\mathrm{CaO}$ & 14.27 & 15.85 & 22.73 & 14.62 & 23.92 & 6.96 & 17.13 & 10.91 & 20.85 \\
\hline $\mathrm{Na}_{2} \mathrm{O}$ & 1.84 & 1.13 & 0.27 & 2.09 & 0.17 & 0.05 & 0.91 & 2.46 & 0.81 \\
\hline $\mathrm{K}_{2} \mathrm{O}$ & 1.06 & 0.47 & 0.08 & 0.75 & 0.01 & 0.02 & 0.29 & 0.63 & 0.2 \\
\hline $\mathrm{P}_{2} \mathrm{O}_{5}$ & 0.101 & 0.058 & 0.087 & 0.032 & 0.061 & 0.015 & 0.09 & 0.12 & 0.39 \\
\hline LOI & 1.28 & 2.37 & 1.92 & 0.92 & 2.32 & 17.43 & 2.30 & 0.64 & 1.47 \\
\hline Total & 100.2 & 100.1 & 100.5 & 100.1 & 100.2 & 98.4 & 99.98 & 100.89 & 99.7 \\
\hline
\end{tabular}

Trace elements (in ppm)

\begin{tabular}{|c|c|c|c|c|c|c|c|c|c|}
\hline $\mathrm{Ba}$ & 220 & 47 & 39 & 56 & 7.9 & 36 & 90 & 260 & 44 \\
\hline $\mathrm{Ce}$ & 30 & 24.5 & 27.7 & 18.6 & 18 & - & $n a$ & $n a$ & $n a$ \\
\hline $\mathrm{Cr}$ & 478 & 494 & 302 & 501 & 655 & 6050 & 425 & 158 & 228 \\
\hline $\mathrm{Ga}$ & 16.6 & 19.6 & 16.8 & 15.1 & 13 & 4 & $n a$ & $n a$ & $n a$ \\
\hline $\mathrm{La}$ & $<4$ & $<4$ & $<4$ & $<4$ & $<4$ & 44 & $n a$ & $n a$ & $n a$ \\
\hline $\mathrm{Nb}$ & 4.5 & 5.3 & 3.9 & 1.5 & 1.2 & - & 5 & 5 & $n a$ \\
\hline $\mathrm{Nd}$ & 14 & 24 & 10 & $<8$ & 10.9 & - & $n a$ & $n a$ & $n a$ \\
\hline $\mathrm{Ni}$ & 131 & 186 & 79 & 87 & 61 & 1750 & 153 & 79 & 183 \\
\hline $\mathrm{Pb}$ & 20.1 & 45 & 31 & 29.4 & 39 & - & $n a$ & $n a$ & $n a$ \\
\hline $\mathrm{Rb}$ & 35 & 5.1 & 4.2 & 13.8 & 0.7 & - & 5 & 18 & $n a$ \\
\hline $\mathrm{Sc}$ & 46 & 53 & 34 & 38 & 33 & - & $n a$ & $n a$ & $n a$ \\
\hline $\mathrm{Sr}$ & 287 & 396 & 196 & 216 & 211 & 61 & 77 & 138 & 334 \\
\hline $\mathrm{V}$ & 246 & 289 & 200 & 129 & 124 & 55 & 216 & 274 & 276 \\
\hline $\mathrm{Y}$ & 27.6 & 28.9 & 21 & 15.4 & 18 & - & 20 & 24 & 32 \\
\hline $\mathrm{Zn}$ & 66 & 70 & 30 & 51 & 64 & 32 & 78 & 99 & $n a$ \\
\hline $\mathrm{Zr}$ & 79 & 78 & 61 & 21.1 & 19.4 & - & 76 & 75 & 161 \\
\hline Sm & 2.912 & 2.161 & & 12.448 & 1.026 & 0.024 & & & \\
\hline $\mathrm{Nd}$ & 11.491 & 8.671 & & 4.675 & 3.862 & 0.104 & & & \\
\hline${ }^{147} \mathrm{Sm} /{ }^{144} \mathrm{Nd}$ & 0.1532 & 0.1506 & & 0.161 & 0.1606 & 0.1409 & & & \\
\hline${ }^{143} \mathrm{Nd} /{ }^{144} \mathrm{Nd}$ & 0.511772 & 0.511771 & & 0.511592 & 0.511699 & 0.51167 & & & \\
\hline \pm & 6 & 6 & & 13 & 22 & 15 & & & \\
\hline $\mathrm{E}(0)$ & -16.89 & -16.91 & & -20.4 & -18.31 & -18.88 & & & \\
\hline $\mathrm{T}_{\mathrm{DM}}(\mathrm{Ga})$ & 3.25 & 3.11 & & 4.43 & 4.02 & 2.89 & & & \\
\hline $\mathrm{Zr} / \mathrm{Y}$ & 2.9 & 2.7 & 2.9 & 1.4 & 1.1 & & 3.8 & 3.12 & 5.0 \\
\hline $\mathrm{Zr} / \mathrm{Nb}$ & 17.6 & 14.7 & 15.6 & 14.1 & 16.2 & & 15.2 & 15 & \\
\hline $\mathrm{Y} / \mathrm{Nb}$ & 6.25 & 5.55 & 5.26 & 10.00 & 14.28 & & 4.0 & 4.8 & \\
\hline $\mathrm{Ti} / \mathrm{V}$ & 20.0 & 17.8 & 16.9 & 13.2 & 10.0 & 7.3 & 21.0 & 10.8 & 42.6 \\
\hline $\mathrm{Ti} / \mathrm{Zr}$ & 62.2 & 66.0 & 55.3 & 80.4 & 64.0 & & 59.8 & 99.1 & 73.0 \\
\hline $\mathrm{Ti} / \mathrm{Y}$ & 178.1 & 178.2 & 160.7 & 110.2 & 68.9 & & 227.3 & 309.7 & 367.2 \\
\hline
\end{tabular}

amphibole type (brown) of the gneiss-associated amphibolite dykes and the high average abundances of $\mathrm{SiO}_{2}, \mathrm{TiO}_{2}, \mathrm{P}_{2} \mathrm{O}_{5}$ and low abundances of $\mathrm{MgO}, \mathrm{CaO}$ and $\mathrm{Cr}$ of these dykes compared to similar dykes related to the Santa Luz peridotites (Table 4) we conclude that the two dyke sets may have distinct petrogenesis, although not necessarily too much different in age.
Melt impregnation and ocean-floor metasomatism We interpret the occurrence in the Santa Luz peridotite complex of irregular amphibolite dykes and gabbroic lenses within fully serpentinized peridotites as basic melt percolation in mantle-like peridotites. A number of ophiolite complexes worldwide presents these features (Spray 1982, Paixão \& Nilson 2002, Schalteg- 


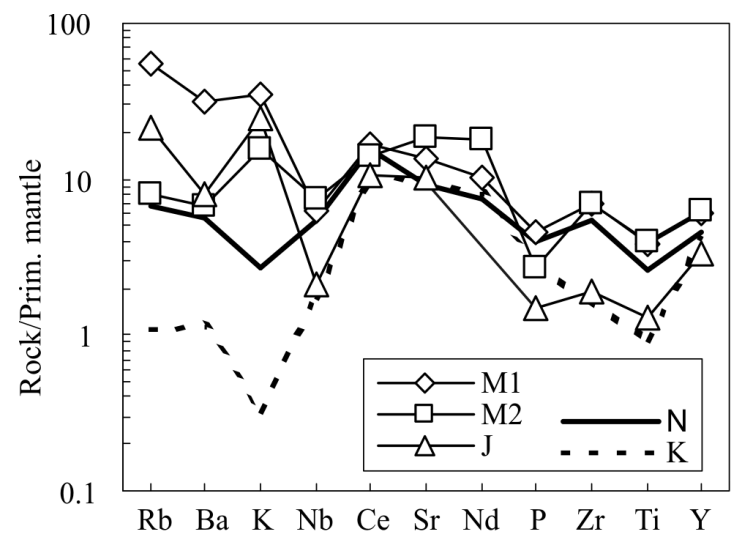

Figure 9 - Mantle-normalized multi-element patterns of mafic dykes intrusive into peridotites of the Santa Luz Peridotite Complex. Individual rock numbers as in Table 4. Normalizing values after Sun \& McDonough (1989).

ger et al. 2002, Muntener \& Piccardo 2003, Rampone et al. 2005). The epidote-rich margins in the intrusive mafic rocks apparently formed during serpentinization of the host peridotite by ocean-floor metasomatism, in a manner similar to rodingitization. The latter process is characterized by the occurrence of various hydrous $\mathrm{Ca}$ Al silicates in veins, such as hydrogrossular, or as replacement products after plagioclase (Honorez \& Kirst 1975).

Implications for the Rio Itapicuru greenstone belt The implications of our discovery for the regional evolution depend on the precise age dating of the Santa Luz peridotite complex and of basalts of the Rio Itapicuru greenstone belt. The timing of peridotite formation and mafic dyke intrusion is bracketed by the ages of an intrusive aplite (2084 $\pm 12 \mathrm{Ma})$ and the regional gneisses $(2983 \pm 8 \mathrm{Ma})$. Yet, the minimum age can be set at ca. $2110 \mathrm{Ma}$, i.e. the age of the Itareru Tonalite (Carvalho \& Oliveira 2003), which is not cut by mafic dykes. On the other hand, basalts of the Rio Itapicuru greenstone belt yielded a $\mathrm{Pb}-\mathrm{Pb}$ isochron at $2209 \pm$ $60 \mathrm{Ma}$ (Silva et al. 2001). Basalts from this greenstone belt are tholeiites of two types: one has geochemical affinities with T- to N-MORB (tholeiite I) and the other (tholeiite II) with continental tholeiites with a marked negative $\mathrm{Nb}$ anomaly (Fig. 10).

The latter type could be representative of basalts erupted during the early opening stage of an ocean basin, whereas the other group would be less evolved and has erupted as transitional to normal ocean-floor basalts. Interestingly, the Rio Itapicuru basalts crop out to the east of the Santa Luz peridotite complex (present day geographic coordinates), i.e. exactly where they should be found in the model of ocean-continent transition of a magma-poor rifted margin, oceanward of the rifted continental margin represented in part by the

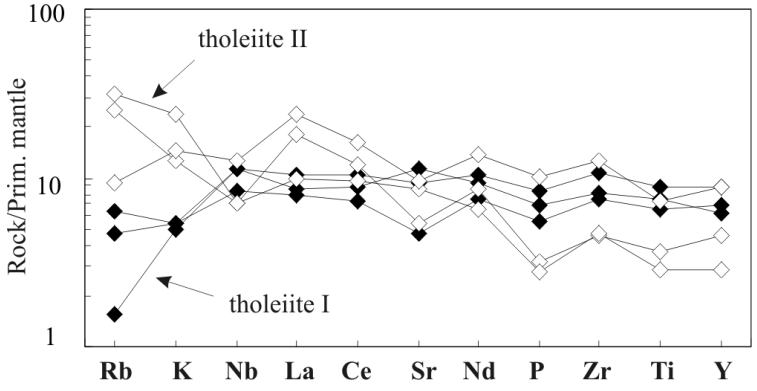

Figure 10 - Mantle-normalized multi-element patterns of basalts of the Rio Itapicuru greenstone belt. Data from Silva (1987). Normalizing values after Sun \& McDonough (1989).

Santa Luz peridotites and associated mafic dykes. In this scenario, the regional banded gneisses (amphibolite dykes and Archaean gneisses) and the interleaved marble lenses, quartzite and metapelitic rocks (garnetbearing paragneisses) would be part also of the rifted continental margin that later underwent deformation during the closure of the ancient Itapicuru ocean by continent-continent collision.

The model put forward here requires further improvements, especially on the precise age dating of mafic dykes of the Santa Luz peridotite complex and of those related to the regional Archaean gneisses, as well as metabasalts of the Rio Itapicuru greenstone belt, a study that is in progress. Nonetheless, this part of the São Francisco craton has an enormous potential to contain one of the world's oldest transitional-type ophiolite formed at a magma-poor rifted continental margin, the study of which and of the regional rocks may help understand the mode of formation of ancient passive margins, their evolution after tectonic inversion, the style of plate tectonics that was in operation in the Palaeoproterozoic time, and contribute to the debate of $\mathrm{Pa}-$ laeoproterozoic supercontinent assembly and breakup.

Acknowledgments The authors would like to thank Lauro Casaes, Virgilio Augusto Pinto, Paulo Roberto Secco and Everton Reis from Magnesita S.A. for kindly giving us permission to study the chromite mine at Santa Luz and for field assistance. Dr. Marcio Pimentel and Dr. Elton Dantas provided the laboratory facilities for $\mathrm{Sm}-\mathrm{Nd}$ isotope analysis at the University of Brasilia. Dr. Silvio Vlach and Mr. Francisco Silva assisted JFB with the microprobe analysis at the Institute of Geosciences at University of São Paulo, and we greatly acknowledge all of them. We are indebted to professor Asit Choudhuri for his review of the final draft. We wish also to thank FAPESP (grants No. 02/07536-4, 99/05760-4, 02/03993-6 and 95/9206-0) and CNPq (302703/2002-0) for research grants to EPO, JFB and MGSA. The comments of two anonymous referees improved considerably the original manuscript and we thank them very much. 


\section{References}

Anonymous 1972. Penrose field conference on ophiolites. Geotimes, 17:24-25.

Araújo M.G.S. 1998. Caracterização Metalogenética do depósito cromitífero de Pedras Pretas, Santa Luz-BA. Dissertação de Mestrado, Instituto de Geociências, Universidade Estadual de Campinas, 138 p.

Bellieni G., Piccirillo E.M. Petrini R., Girardi V.A.V., Menezes Leal A.B., Teixeira W., Bastos Leal L.R., De Min A., Comin Chiaramonti P. \& Tanner de Oliveira M.A.F. 1995. Petrological and Sr-Nd evidence bearing on Early Proterozoic magmatic events of the subcontinental mantle: Sao Francisco craton (Uaua, NE-Brazil). Contr. Miner. Petrol., 122:252-261.

Beslier M.O., Royer J.Y., Hill P., Boeuf E., Buchanan C., Chatin F., Giradeau J., Jacovetti G., Moreau A., Munschy M., Partouche C., Thomas S. \& Robert U. 1999. Mantle exhumation at a rift zone: evidence for a wide oceancontinent transition along the Southwest Australian passive margin. In: EUG10, EUG conference, 4, Abstract, p.3 77.

Beslier M.O., Royer J.Y., Girardeau J., Hill P.J., Boeuf E., Buchanan C., Chatin F., Moreau A., Munschy M., Partouche C., Roberts U. \& Thomas S. 2004. Une large transition continent-océan en pied de marge sud-ouest australienne: premiers résultats de la campagne Margau/ MD110. Bull. Soc. Géol. Fr., 175:629-641.

Bideu D., Hébert R., Hékinian R. \& Cannat M., 1991. Metamorphism of deep seated rocks from the Garrett ultrafast transform (East Pacific Rise near $13^{\circ} 25^{\prime}$ S). J. Geophys. Res., 96: 10079-10099.

Bonatti E., Clocchiatti R., Colantoni P., Gelmini R., Marinelli G., Ottonello G., Santacroce R., Taviani M., AbdelMequid A.A., Assaf H.S. \& El Tahir M.A. 1983. Zabargad (St. John) Island: An uplifted fragment of sub-Red Sea lithosphere. J. Geol. Soc. London, 140:677-690.

Carvalho M.J. \& Oliveira E.P. 2003. Geologia do Tonalito Itareru, Bloco Serrinha, Bahia: uma intrusão sin-tectônica do início da colisão continental no Segmento Norte do Orógeno Itabuna-Salvador-Curaçá. Rev. Bras. Geoc., 33(1-Suplemento):55-68.

Carvalho Filho A.R., Queiroz E.T. \& Leahy G.A.S. 1986. Jazida de cromita de Pedras Pretas, município de Santa Luz, Bahia. In: C. Schobbenhaus \& C.E.S. Coelho (cords.) Principais depósitos minerais do Brasil. DNPM-CVRD, v.1, p. 235-248.

Chazot G., Charpentier S., Kornprobst J., Vannucci R. \& Luais B. 2005. Lithospheric mantle evolution during continental break-up: the West Iberia non-volcanic passive margin. J. Petrol., 46:2527-2568.

Coleman R.G. 1977. Ophiolites. Ancient oceanic lithosphere? Springer-Verlag, $229 \mathrm{p}$.

Condie K.C. 2005. Earth as an evolving planetary system. Elsevier Academic press, $447 \mathrm{p}$.

Dick H.J.B. \& Bullen T. 1984. Chromian spinel as a petrogenetic indicator in abyssal and alpine-type peridotites and spatially associated lavas. Contr. Miner. Petrol., 86: 54-76.

Eales H.V. \& Reynolds I.M. 1986. Cryptic variations within chromitites of the Upper Critical zone, northwestern Bushveld Complex. Econ. Geol., 81:1056-1066.

Floyd P.A. 1989. Geochemical features of intraplate oceanic plateau basalts. In: A.D. Saunders \& M.J. Norry (eds.) Magmatism in the Ocean Basins. Geological Society of London Special Publication, v.42, p. 215-230.

Gioia S.M.C.L. \& Pimentel M.M. 2000. The Sm-Nd isotopic method in the geochronology laboratory of the University of Brasília. An. Acad. Bras. Ciênc., 72:219-245.

Gladczenko T.P., Hinz K., Eldholm O., Meyer H., Neben S. \& Skogseid J. 1997. South Atlantic volcanic margins. J. Geol. Soc. London, 154:465-470.

Hellebrand E., Snow J.E., Dick H.J.B. \& Hofmann A.W. 2001. Coupled major and trace elements as indicators of the extent of melting in mid-ocean-ridge peridotites. Nature, 410:677-681.

Hergt J.M., Peate D.W. \& Hawkesworth C.J. 1991. The petrogenesis of Mesozoic Gondwana low-Ti flood basalts. Earth Plan. Sci. Lett., 105:134-148.

Honorez J. \& Kirst P. 1975. Petrology of rodingites from the equatorial Mid-Atlantic fracture zones and their geotectonic significance. Contr. Miner. Petrol., 49:233-257.

Kusky T.M. 2004. Introduction. In:_ (ed.) Precambrian ophiolites and related rocks. Developments in Precambrian Geology. Elsevier, cap. 13, p. 1-34.

Manatschal G. 2004. New models for evolution of magmapoor rifted margins based on a review of data and concepts from West Iberia and the Alps. Inter. J. Earth Sci., 93:432-466.

Mascle J., Basile C., Pontoise B. \& Sage F. 1995. The Cote D'Ivore-Ghana transform margin: an example of an ocean-continent transfor boundary. In: E. Banda et al. (eds.) Rifted Ocean-Continent Boundaries. Kluwer Academic Publish., p. 327-339.

Marques J.C. \& Ferreira Filho C.F. 2003. The chromite deposit of the Ipueira-Medrado sill, São Francisco craton, Bahia State, Brazil. Econ. Geol., 98:87-108.

Mathez R.H. \& Peach C.L. 1989. The geochemistry of the platinum-group-elements in mafic and ultramafic rocks. In: J.A. Whitney \& A.J. Naldrett (eds.) Ore deposition associated with magmas. Reviews in Economic Geol$o g y$, v. 4, Society of Economic Geologists, p. 33-43.

Muntener O. \& Piccardo G.B. 2003. Melt migration in ophiolites: the message from Alpine-Apennine peridotites and implications for embryonic ocean basins. In: Y. Dilek \& P.T. Robinson (eds.) Ophiolites in Earth History. Geological Society of London Special Publication, v.218, p. 69-89.

Naldrett A.J. \& Duke J.M. 1980. Platinum metals in magmatic sulphide ores. Science, 208:1417-1424.

Nicolas A., Boudier F. \& Montigny R. 1987. Structure of Zabargad Island and early rifting of the Red Sea. J. Geophys. Res., 92(B1):461-474.

Oliveira E.P., Choudhuri A, Carvalho M.J., Souza A, Lazaretti A.F., Daleffe D.L., Azevedo E.J., Oliveira E.F., Cuoco F., Tezini F.C., Carvalho J.A., Braga P.S. \& Battestin TN. 2002. Mapa geológico da região de Santa Luz - Bahia, 1:25.000. Trabalho de Campo II, Instituto de 
Geociências, Universidade Estadual de Campinas.

Oliveira E.P., Carvalho M.J. \& McNaughton N. 2004. Evolução do segmento norte do Orógeno Itabuna-SalvadorCuraçá: cronologia da acresção de arcos, colisão continental e escape de terrenos. Rev. Geol. USP - Série Científica, 4:41-53.

Oliveira E.P. \& Knauer L.G. 1993. Corpos Máficos e Ultramáficos do craton do São Francisco. In: J.M.L. Dominguez \& A. Misi (eds.) O Cráton do São Francisco. Salvador, SBG/SGM/CNPq, p. 119-136.

Oliveira E.P., Tarney J. \& João X.J. 1990. Geochemistry of the Mesozoic Amapa and Jari Dyke Swarms, Northern Brazil: plume-related magmatism during the opening of the Central Atlantic. In: A.J. Parker, P.C. Rickwood \& D.H. Tucker (eds.) Mafic Dykes and Emplacement Mechanisms. A.A. Balkema, Rotterdam, p. 173-183.

Oliveira E.P., Escayola M. \& Araújo M.G.S. 2005. Is the melt-impregnated Santa Luz chromite peridotite, BahiaBrazil, an early stage ophiolitic peridotite remnant of the Rio Itapicuru greenstone belt evolution? In: Simpósio sobre o Cráton do São Francisco, 3, Salvador, Bahia, Anais, p. 106-109.

Paixão M.A.P. \& Nilson A.A. 2002. Geologia e petrologia dos cromititos podiformes e rochas associadas do complexo Quatipuru, sudeste do Estado do Pará. In: Congr. Bras. Geologia, 16, João Pessoa, Anais, p. 423.

Peate D.W. 1997. The Paraná-Etendeka Province. In: J.J. Mahojey \& M.F. Coffin (eds.) Large Igneous Provinces: continental, oceanic, and planetary flood volcanism. American Geophysical Union, Geophysical Monograph, v. 100, p. $217-245$.

Petrini R., Joron J.L., Ottonello G., Bonatti E. \& Seyler M. 1988. Basaltic dykes from Zabargad Island, Red Sea: petrology and geochemistry. Tectonophysics, 150:229248.

Piccardo G.B. 2003. Mantle processes during ocean formation: petrologic records in peridotites from the AlpineApennine ophiolites. Episodes, 26:193-199.

Puga E., Nieto J.M., Diaz de Federico A., Bodinier J.L. \& Morten L. 1999. Petrology and metamorphic evolution of ultramafic rocks and dolerite dykes of the Betic Ophiolitic Association (Mulhacén Complex, SE Spain): evidence of eo-Alpine subduction following an ocean-floor metasomatic process. Lithos, 49:23-56.

Rampone E. \& Piccardo G.B. 2000. The ophiolite-oceanic lithosphere analogue: New insights from the Northern Apennine (Italy). In: J. Dilek, E. Moores, D.Elthon \& A. Nicolas (eds.) - Ophiolites and Oceanic Crust: New insights from Field Studies and Ocean Drilling program. Geol. Soc. Amer. Spec. Paper, v.349, p. 21-34.

Rampone E., Romairone A., Abouchami W., Piccardo G.B. \& Hofmann A.W. 2005. Chronology, Petrology and Isotope Geochemistry of the Erro-Tobbio Peridotites (Ligurian Alps, Italy): Records of Late Palaeozoic Lithospheric Extension. J. Petrol., 46:799-827.

Rösli U., Hoernes S. \& Köppel V. 1991. Isotope data of metarodingites and associated rocks from the Lanzo and the Bracco ophiolitic massifs: indication on the evolution of the Alpino-type ultramafic-mafic complexes.
Schweiz. Mineral. Petrogr. Mitt., 71:125-141.

Schaltegger U., Desmurs L., Manatschal G., Müntener O., Meier M., Frank M. \& Bernoulli D. 2002. The transition from rifting to sea-floor spreading within a magma-poor rifted margin: field and isotopic constraints. Terra Nova, 14:156-162.

Silva M.G. 1987. Petrologie,Geochemie und tektonische Entwicklung eines proterozoischen Grunsteingurtels: Rio Itapicuru, Bahia, Brasilien. Doktorarbeit, Universitaet Freiburg, 180 p.

Silva M.G., Coelho C.E.S., Teixeira J.B.G., Alves da Silva F.C., Silva R.A. \& Souza J.A.B. 2001. The Rio Itapicuru greenstone belt, Bahia, Brazil: geologic evolution and review of gold mineralization. Miner. Deposita, 36: 345-357.

Smith B., Barley M.E., Groves D.I., Krapez B., McNaughton N.J., Bickle M.J. \& Chapman H.J. 1998. The Scholl Shear Zone, West Pilbara: evidence for a domain boundary structure from integrated tectonostratigraphic analyses, SHRIMP U-Pb dating and isotopic and geochemical data of granitoids. Precambrian Res., 88:143171.

Snow J.E. \& Schmidt G. 1999. Proterozoic melting in the northern peridotite Massif, Zabargad Island: Os isotopic evidence. Terra Nova, 11:45-50.

Souza J.D., Kosin M., Melo R., Oliveira E.P., Carvalho M.J. \& Leite C.M.M. 2003. Guia de excursão - Geologia do segmento norte do orógeno Itabuna-Salvador-Curaçá. Rev. Bras. Geoc., 33 (I-Suplemento):27-32.

Spier C.B. \& Ferreira Filho C.F. 2001. The chromite deposits of the Bacuri mafic-ultramafic layered complex, Guyana shield, Amapá State, Brazil. Econ. Geol., 96:817-835.

Spray J.G. 1982. Mafic segregations in ophiolite mantle sequences. Nature, 299:524-528.

Suita M.T. F. \& Strider A.J. 1996. Cr-spinels from Brazilian mafic-ultramafic complexes: metamorphic modifications. Inter. Geol. Rev., 38:245-267.

Sun S.-S. \& McDonough W.F. 1989. Chemical and isotope systematics of oceanic basalts: implications for mantle composition and processes. In: A.D. Saunders \& M.J. Norry (eds.) Magmatism in the Ocean Basins. Geological Society of London Special Publication, v.42, p. 313345.

Von Gruenewaldt G. \& Merkle R.K.W. 1995. Platinum group element proportions in chromitites of the Bushveld complex: implications for fractionation and magma mixing models. J. Afric. Earth Sci., 21:615-632.

Whitmarsh R.B., Manatschal G. \& Minshull T.A. 2001. Evolution of magma-poor continental margins from rifting to seafloor spreading. Nature, 413:150-154.

Wilson R.C.L., Whitmarsh R.B., Taylor B. \& Froitzheim N. (Eds.) 2001. Non-volcanic rifting of continental margins: A comparison of evidence from land and sea. Geological Society of London Special Publication, 187 p.

Windley B.F. 2005. Precambrian ophiolites and related rocks. Book review. Precambrian Res., 138:181-182.

Manuscrito CSF-10 Submetido em 31 de maio de 2006 Aceito em 24 de novembro de 2006 